\title{
PRE DIALYSIS PATIENTS; FREQUENCY OF MALNUTRITION IN CHRONIC KIDNEY DISEASE
}

1. Assistant Professor SIUT, Sindh Institute of Urology \& Transplantation Karachi

2. Senior Nephrologist LUMHS.

3. Assistant Professor Surgery LUMHS Jamshoro.

4. Assistant Professor Medicine LUMHS.

5. Student in LUMHS

Correspondence Address: Dr. Santosh Kumar

Assistant Professor Medicine LUMHS.

dr_santosh72@yahoo.com

Article received on:

20/08/2016

Accepted for publication: 27/12/2016

Received after proof reading: $14 / 02 / 2017$

\section{Syed Hidayet Ali ${ }^{1}$, Dr. Bagwan Das ${ }^{2}$, Dr. Agha Taj ${ }^{3}$, Dr. Santosh Kumar ${ }^{4}$, Besham Kumar ${ }^{5}$}

ABSTRACT... Introduction: Chronic kidney disease (CKD) is an alarmingly increasing condition from day to day andit is assumed that malnutrition is co-existent in patients with chronic renal failure (CRF). Malnutrition also occurs in pre-dialysis patients. Such patients have reduced body weight, depleted fat (energy) stores, loss of somatic protein (low muscle mass) and low levels of different plasma proteins like pre-albumin albumin, transferrin, and others. Objective: To ascertain the frequency of malnutrition in dialysis independent patients of chronic kidney disease. Setting: Department of nephrology, Jinnah Postgraduate Medical Centre Karachi. Duration of study: 6 month from 1 June 2013 - 1 December 2013. Study design: cross sectional study. Subjects and methods: Patients with chronic kidney disease (GFR $<60 \mathrm{ml} / \mathrm{min} / 1.73 \mathrm{~m}^{2}$ ) on conservative management irrespective of cause and sex were studied. All Patients with CKD stage 3 and onwards i. ecreatinine clearance less than 60ml/ $\mathrm{min} / 1.73 \mathrm{~m}^{2}$ for more than 6 months were considered. Descriptive analysis of these patients was done by: Calculating mean $\pm S D$ for age and duration of disease. Male to female ratio was calculated. Frequency of malnutrition in undialysed patients was calculated. The effect modifier of age, gender, duration of disease was controlled through stratification. Chi square test was applied and $p$ value $\leq 0.05$ was taken as significant. Result: Out of 137 patients, 80 were males and 57 were females and the mean age of patients was $58 \pm 5.8$. Mean duration of disease was $5.2 \pm 1.05$. Moderate malnutrition cases were $58(42.3 \%)$ while severe malnutrition was observed in $32(23.35 \%)$ cases. Conclusion: Patients of chronic kidney disease were found to be at risk of malnutrition.

Keywords: Malnutrition, chronic kidney disease, dialysis, serum albumin.

Article Citation: Ali SH, Das B, Taj A, Kumar S, Kumar B. Pre dialysis patients; frequency of malnutrition in chronic kidney disease. Professional Med J 2017;24(2):267272. DOI: $10.17957 / T P M J / 17.3575$

\section{INTRODUCTION}

Mal nutrition and CKD is a common problem in socio economic developing country of South Asia. Chronic kidney disease (CKD) is a condition that has got an increment in its prevalence throughout the world.Chronic renal failure compensated or decompensated on haemodialysis mostly had been found wasted and malnutrition with loss of weight especially fat and protein like prealbumin, albumin, transferin. Many article published in recognized journals there results shows that up to 70 percent of malnutrition and weight loss found and in peritoneal dialysis upto 45 percent. ${ }^{1-4}$ Such variation in the prevalence ratio of malnutrition is probably associated with elements like age, different case of complication of diabetes with renal failure or diabetic nephropathy and diabetic neuropathy and hypercalemia, hyperuracemia, hypertension and with chronic heart failure..$^{5,6}$ there are many factors associated with weight loss or mal nutrition in chronic kidney disease which indirectly or directly involved in anorexia, repeated infection bony osteo dystrophy microcytic anemia megaloblastic anemia neurological manifestation, and cardiovascular presentation in renal dialysis patients. ${ }^{7}$ The overall malnourishment incidence in CKD cases is $37-84 \%$. The prevalence of malnutrition in CKD patients was calculated to be $65 \%$ in an Indian study. ${ }^{8}$ It is an important recognized predictor of mortality and morbidity. Nutritional status of patient is an important and modifiable factor that may influence disease process and outcome in chronic kidney disease. ${ }^{9}$ Abnormal catabolism of albumin or loss of protein in haemodialysis or protein urea are main source of mal nutrition 
in chronic kidney disease. ${ }^{10}$ Malnutrition usually manifests as hypoproteinemia and reduced muscle mass. ${ }^{11}$

Several anthropometric, clinical, and biochemical indices like, serum albumin and prealbumin, cholesterol, transferrin and Dual X-ray Energy Absorptiometry (DEXA) have been used to assess nutrition. ${ }^{8}$ Total body nitrogen quantifies the protein content and considered gold standard. The other methods are expensive, cumbersome and impractical to be carried out. ${ }^{12}$

Serum albumin is an important factors in CKD. Several studies have identified hypo-albuminemia as the strongest fore-teller of mortality and morbidity. ${ }^{13}$ It is also an independent fore-caster of cardiovascular system disease in early CKD. ${ }^{14}$ Predialysis serum albumin $<2.9 \mathrm{~g} / \mathrm{dl}$ greatens the jeopardy of left ventricular hypertrophy. ${ }^{15}$ Low BMl is also an indicator of malnutrition and values less than $20 \mathrm{~kg} / \mathrm{m}^{2}$ have been shown to be a predictor of mortality in patients with CKD. ${ }^{16,17}$ The score derived in SGA is based on features that are obvious both in patient's history and in physical examination. ${ }^{18}$ Malnutrition is associated with significant mortality in CKD population, but little is known about the local data. Kaneez et al show $97 \%$ dialysis dependent patients are suffering from malnutrition. ${ }^{19}$ As, this study has not considered the CKD patients independent of dialysis. This study will aid in estimating the frequency of malnutrition in our pre-dialysis CKD patients as well as it will alert the clinician to take suitable measures to avoid malnourishment in time and hence the morbidity.

\section{METHODOLOGY}

Data was collected from the patients enrolled in the study. Informed consent was taken. The confounding variables were controlled by excluding the patients suffering from gastrointestinal disease, nephrotic syndrome, tuberculosis sepsis, shock, dementia and patients using steroids and other immunosuppressive agents.

Diagnosis of chronic kidney disease was made with the help of detailed history, relevant physical examination and laboratory investigation. GFR was calculated using Cock Craft Gault formula. Nutritional status was measured by SGA scoring BMI was calculated by measurement of height and weight. And BMl of $<20 \mathrm{~kg} / \mathrm{m}^{2}$ was labeled as malnourished. Tricep skin fold. Male $<6 \mathrm{~mm}$, female $<8 \mathrm{~mm}$ were labeled as malnourished. We measure mid arm circumference if it less Values $<20 \mathrm{~cm}$ in male and $<18.5 \mathrm{~cm}$ in female were labeled as malnutrition.

The patients were classified in 3 SGA grades: $A=$ well nourished (score $1-10), B=$ moderate malnourished (11-25), $C=$ severely malnourished (26-35). SGA Performa is attached as annexure. All relevant information was filled on a Performa attached as annexure-1.

The data will be analysed through statistical package of social science (SPSS version 15.0) the anthropometric variables will be presented by the mean \pm SD and classified in to groups of malnutrition according to their cut-off. The SGA score based on seven points criteria will be presented by mean \pm SD for all the patients. The grading of SGA will also be made for three categories of well-nourished moderately malnourished and severely malnourished.

Descriptive analysis of the patients will be done by calculating mean \pm SD for age male to female ratio. Frequency of malnutrition in un-dialyzed patient will be calculated. The effect modifier of age will be grouped into decades; gender will be grouped in male and female to know any association of individual group. An inferential test of significance will not be applicable for this descriptive study.

\section{RESULTS}

One hundred and thirty seven patients were enrolled in the study and no patient was excluded after enrollment. At enrollment all patients were similar in terms of demographic characteristics.

Mean age of patients was 58.3 years with the standard deviation of 5.87 . 
Out of 137 patients, $3(2.18 \%)$ patients were between 15-25 years, 10(7.29\%) were between 25-35 years of age, $40(29.19 \%)$ were between 3645 years of age, 32(23.35\%) were between 4655 years of age, 15(10.94\%) were between 66-70 years of age while, $7(5.10 \%)$ patients were more than 75 years of age.

Out of 137 patients, male to female ratios was $2: 1$. Male were $80(58.4 \%)$ while $57(41.6 \%)$ were female.

Mean duration of disease was 5.27 years with the standard deviation of \pm 1.05 in total patients of 137. The mean GFR was $40.3 \mathrm{ml} / \mathrm{min} / 1.73 \mathrm{mwith}$ the standard deviation of $16.8 \mathrm{ml} / \mathrm{min} / 1.73 \mathrm{~m}^{2}$ out 137 patients.

Of these patients 78(56.9) were in stage 3 and $59(43.06)$ were in stage 4 while no patients was found with in the category of stage 5 in predialysis cases of chronic kidney disease.

Out of 137 patients $37(27 \%)$ patients were found with $<18.5 \mathrm{~kg} / \mathrm{m}^{2}$ body mass index, $32(23.4 \%)$ patients were found in between $18.5-20 \mathrm{~kg} / \mathrm{m}^{2}$ body mass index while, 68 (49.6\%) patients were found with $>20 \mathrm{~kg} / \mathrm{m}^{2}$ body mass index. The mean body mass index was $45.66 \mathrm{~kg} / \mathrm{m}^{2}$ with the standard deviation of $\pm 1.95 \mathrm{~kg} / \mathrm{m}^{2}$.

Out of 137 patients the minimum age was 45 years and the maximum was 75 years as shown in frequency of nourished, moderately malnourished and severely malnourished with respect to age groups shows In 45-50 years of ages 15 (10.95\%) were nourished while no one was moderately or severely malnourished in these groups, in between $51-55$ years of age, $13(9.48 \%)$ were nourished, $3(2.18 \%)$ were moderately nourished while 6 $(4.38 \%)$ were severely malnourished, in between $56-60$ years of age 11 (8.02\%) were nourished, $43(31.39 \%)$ were moderately nourished while $6(4.38 \%)$ were severely malnourished, in between 61-65 years of ages $7(5.10 \%)$ were nourished, 11 (8.02\%) were severely nourished while no one was moderately malnourished, in between 65-70 years of ages no one was nourished 12 (8.76\%) were moderately nourished and $3(2.18 \%)$ were severely malnourished and patients with ages more than $70 \%$ only 1 patient was nourished, no one was moderately malnourished and 6 (4.98\%) were severely malnourished.

In $80(58.48 \%)$ male gender $39(83.3 \%)$ patients were nourished, 38 (65.4\%) were moderately malnourished and 3(9.4\%)) were severely malnourished while, in $57(41.6 \%)$ of females $8(17 \%)$ were nourished, $20(34.5 \%)$ were moderately malnourished and 29 (90.6\%) were severely malnourished according to Subjective Gold Assessment Test scores out of 137 total number of patients.

Duration of chronic kidney disease showed in 4, 5,6 and 7 years 26(55.3\%), 11(23.4\%), 5(10.6\%), $5(10.6 \%)$ were nourished, $10(17.2 \%), 39(67.2 \%)$, $9(15.5 \%), \quad 0$ were moderately malnourished while $0,7(12.5 \%), 14(21.9 \%)$ and $21(65.6 \%)$ patients were severely malnourished respectively according to Subjective Gold Assessment Test scores.

Chi-Square test shows there is a significant association in frequency of malnutrition in undialysed patients of chronic kidney disease i.e. $p=0.00$.

\section{DISCUSSION}

Our study demonstrates evidence that undialyzed patients of malnutrition. The stages 3 to 5 of CKD account for malnutrition. Though malnutrition is the mighty prophet of CKD but it is not considered as the major cause of death; however, the connection between malnutrition and atherosclerosis has been signified. ${ }^{20}$

Mean age of patients in our research study was 58.3 years with the standard deviation of \pm 5.87 . This fact was supported by available literature from Morocco. Moncef et $\mathrm{al}^{20}$ describes mean age 52 years with the standard deviation of \pm 14 , Sirinavasan et al from United States describes mean age 71 years with the standard deviation of \pm 10.7 and Detsky et al from Canada shows mean age 52.7years with the standard Deviation 
of \pm 17.7 . Similar pattern was observed in studies by Valderra' banoet $\mathrm{al}^{68}$ which shows mean age of patient 59.1 years with the standard deviation of \pm 15.6 .

The ratio of male and female in our study was 2:1 which correlates well with that observed in different studies from Switzerland. ${ }^{21}$ Same results were declared in the available literature from Thailand ${ }^{65}$, and Ohio. ${ }^{69}$ Duration of Disease in our study was 4-7 years.

The Mean of duration of Disease was found to be 5.27 years with the standard deviation of \pm 1.05 . On their booking visit to the dialysis center, $57.3 \%$ of the patients (total no 3918) had been under the supervision of a nephrologists for $>1$ year, $31.4 \%$ had been under the supervision of a nephrologists for $<6$ months and $14.1 \%$ for $<1$ month (89 full). ${ }^{22}$

We made BMI our tool to determine malnutrition. The mean Body Mass Index was found to be 45.66 $\mathrm{kg} / \mathrm{m}^{2}$ with the Standard Deviation of $\pm 1.95 \mathrm{~kg} / \mathrm{m}^{2}$ in our Study. Unlike general population, high BMI in dialysis dependent patients has been shown to reveal better prognosis. Moncef et al, shows in his studies the mean of BMI for all patients was $23 \pm$ $4 \mathrm{~kg} / \mathrm{m}^{2}$ (for females $23 \pm 4 \mathrm{~kg} / \mathrm{m}^{2}$ and for males $\left.24 \pm 4 \mathrm{~kg} / \mathrm{m}^{2}\right)$. The patients were assorted into two categories relying on BMI. Twenty-six (71\%) patients had a normal nutritional status (group I) and $11(29 \%)$ patients were considered to be malnourished (group II). We used BMI as our tool to determine the incidence of protein-energy malnutrition in our research, which is the indicator of malnutrition. The prevalence of malnutrition, according to BMI, was $29 \%$. Malnutrition prevalent cases were $29 \%$ in accordance with BMI. This value was higher in comparison with the most previously reported studies. ${ }^{21,22}$ The SGA tool has been evaluated in different patient populations throughout the world and has been used for over 20 years and produced consistent results. SGA is the only malnutrition screening tool recommended by the AS-PEN board of directors, and a patient-generated SGA is in routine clinical use. $^{23}$
Malnourishments assessment shows highest of moderately malnourished patients in between ages 56-60 years than in 66-70 years of age group. Frequency of severely malnourished patients was higher in 61-65 years of age group. Frequency of nourished patients was higher in 45-50 years of age group. In progressive CKD patients, who receive a protein restricted diet, the protein content should not be lesser than 0.75 g per kilogram ideal body weight (IBW) per day andatleast $50 \%$ of high biological value protein is appreciable.

A person should take $35 \mathrm{Kcal} / \mathrm{Kg} / \mathrm{IBW} /$ day in order to lessen the peril of protein-energy malnutrition; such patients must consider a low protein diet.

Patients who are on maintenance dialysis including peritoneal dialysis are in jeopardy of moderate to severe malnutrition. Malnutrition is commonly seen as the patient commences dialysis. Often the caloric intake is inadequate in the latter stages of CKD (pre-dialysis), with generalized lethargy, anorexia, mood changes and metabolic acidosis prevailing. A lack of caloric intake results in protein consumption for energy, diminished muscle mass, and proteincalorie imperfect nourishment. Such complication is worth-worrying as the malnutrient patient has high mortality rate. ${ }^{22,23}$

The safety of low protein diets was assessed in an analysis of patients in the Modification of Diet in Renal Disease (MDRD) is a study conducted by Kopple et al 1997,Klahr et al 1994, in which the pros and safety of low protein diet was assessed in patients. In this research trial, subjects were kept on a usual protein diet ( $1.3 \mathrm{~g} / \mathrm{kg}$ per day), a low protein diet $(0.58 \mathrm{~g} / \mathrm{kg}$ per day) or a very low protein diet $(0.3 \mathrm{~g} / \mathrm{kg}$ per day supplemented with a keto acid-amino acid mixture at $0.28 \mathrm{~g} / \mathrm{kg}$ per day), dependingupon their glomerular filtration rate (GFR). On an average follow-up of 2.2 years, a low protein intake was not related with increased rates of mortality, hospitalization or malnutrition.

Anyway, diminished levels of protein ingestion were associated with diminished energy intake 
and significant but small absolute declines in serum transferrin, body weight, percent body fat, and arm muscle area.

As a result, although protein restriction may be safe for two to three years, declines in some nutritional indices are noticed. The basic standard dietary energy taking in this study can be considered inadequate for the nutritional needs of the nondialysed patient since it has been suggested that their energy expenditure and requirements are not different compared with the normal community. ${ }^{21,22,23}$

\section{CONCLUSION}

The frequency of malnutrition in undialyzed patients of chronic kidney disease was found to be high. Moderate malnourishment was higher than severe malnourishment.

\section{Copyright@ 27 Dec, 2016.}

\section{REFERENCES}

1. Danielsson A, Qureshi AR, Divino-Filho JC, Lindholm B, Gutierrez A, Alvestrand A et al. "A cross-sectional study on elements affecting malnutrition in hemodialysis patients." \{Kidney\}Int 1998; 53: 773-82.

2. Wouters EF, Buurman WA, Simons JP, Scols AM. "Relationship of Weight loss and low body cell mass in males with lung cancer" with "acute-stage feedback, intrinsic inflammation, resting energy Expenditure, catabolic and anabolic hormones. ClinSci since 1999; 97:215-23.

3. Munro R, Capell $\mathrm{H}$. Prevalence of low body mass in rheumatoid Arthritis: associations with the acute stage feedback. Ann RheumDis1997; 56:326-9.

4. Stenvinkel P, Heimbu" rger O, Paultre F et al. Strong associations between malnutrition, inflammation and atherosclerosis in chronic renal failure. Kidneylnt 1999; 55: 1899- 1911.

5. Prakash J, Raja R, Mishra RN, Vohra R, Sharma N, Wani IA, et al. High prevalence of malnutrition and inflammation in undialyzed patients with chronic renal failure in developing countries: a single center experience from eastern India. Ren Fail. 2007; 29:8116.

6. Khan MS, Chandanpreet S, Kewal K, Sanjay D, Ram KJ, Atul S. Malnutrition, anthropometric and biochemical abnormalities in patients with diabetic nephropathy. J RenNutr, 2009; 19:275-80.
7. Agaba El, Agaba PA. Prevalence of malnutrition in Nigerians with chronic renal failure. IntUrolNephrol. 2004; 36:89-93.

8. Tayyem RF, Mrayyan MT, Assessing the prevalence of malnutrition in chronic kidney disease patients in Jordan. J RenNutr, 2008; 18:202-9.

9. 1Shan NR, Dumler F. Hypoalbuminemia a marker of cardiovascular disease in patients with chronic kidney disease stages II-IV. Int J Med Sci. 2008;5:36670 .

10. Siddiqui UA, Halim A, Hussain T. Nutritional profile and inflammatory status of stable chronic hemodialysis patients at nephrology department, Military Hospital Rawalpindi. J Ayub Med Coll Abottabad. 2007; 19:2931.

11. Moon KH, Song IS, Yang WS, Shin YT, Kim SB, Song JK, et al. Hypoalbuminemia as a risk factor for progressive left-ventricular hypertrophy in hemodialysis patients. Am J Nephrol. 2000; 20:396401.

12. Leavey SF, McCullough K, Hecking E, Goodkin D, Port $\mathrm{FK}$, Young EW. Body mass index and mortality in 'healthier' as compared with sicker haemodialysis patients: results from the dialysis outcomes and practice patterns study (DOPPS). Nephrol Dial Transplant. 2001; 16:2386-94.

13. FalakGurrebun, George H. Hartely. Nutritional screening in pts on hemodialysis: is SGA an appropriate tool? Journal of renal nutrition vol: 17 no. 2 (March). 2007.114-117.

14. Zehra, Kaneez. Frequency of malnutrition inflammation complex syndrome in patients with end stage renal failure on maintenance hemodialysis at Jinnah Postgraduate Medical Centre, Karachi. (Dissertation Nephrology), Karachi: College of Physician \& Surgeon Pakistan, 2009.

15. Stenvinkel $P$, Heimburger $O$, Lindholm $B$, Kaysen GA, Berg-strom J: Are there two types of malnutrition in chronic renal failure? Evidence for relationships between malnutrition, inflammation and atherosclerosis (MIA syndrome). Nephrol Dial Transplant. 2000;15:953-60.

16. Moncef E M'Barki K, Rhita B, Zouhir O. Factors Predicting Malnutrition in Hemodialysis Patients. Saudi J Kidney Dis Transpl 2011;22(4):695-704.

17. Srinivasan B, Pappas L, Ramkumar N, Matthew $H$. Malnutrition and atherosclerosis in dialysis patients. J Am SocNephrol. 2004;15:733-42.18. 
18. Detsky AS, McLaughlin JR, Baker JP, Johnston N, Whittaker S, Mendelson RA, et al. What is subjective global assessment of nutritional status? 1987.

Classical article. Nutr Hosp. 2008 Jul-Aug;23(4):400-7.

19. Valderrabaono F, Horl W, Macdougall I, Rossert J, Rutkowski B, Wauters J. PRE-dialysis survey on anaemia management. Nephrol Dial Transplant. 2003;18:89-100.

20. Weaver D, Kimball T, Knilans T, Mays W Knetch S, Gerdis Y, Glascock B et al. Decreased Maximal Aerobic Capacity in Pediatric Chronic Kidney Disease. J Am SocNephrol.2008;19:624-30,
21. Stenvinkel $P$, Heimburger $O$, Lindholm $B$, Kaysen GA, Berg-strom J. Are there two types of malnutrition in chronic renal failure? Evidence for relationships between malnutrition, inflammation and atherosclerosis (MIA syndrome). Nephrol Dial Transplant. 2000;15:953-60.

22. Leavey SF, McCullough K, Hecking E, et al. Body mass index and mortality in 'healthier' as compared with 'sicker' haemodialysis patients: results from the Dialysis Outcomes and Practice Patterns Study (DOPPS). Nephrol Dial Transplant 2001;16:2386-94.

23. Voss D. Protein in pre-dialysis patients. The CARI Guidelines. 2004.

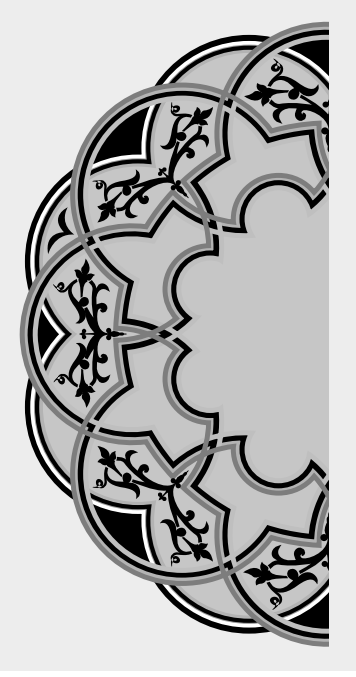

\title{
"The best preparation for tomorrow is doing your best today."
}

\author{
H. Jackson Brown, Jr.
}

\section{AUTHORSHIP AND CONTRIBUTION DECLARATION}

\begin{tabular}{|c|c|c|}
\hline Sr. \# & Author-s Full Name & Contribution to the paper \\
\hline 1 & Syed Hidayet Ali & $\begin{array}{l}\text { Idea, Contribution in collection } \\
\text { sample }\end{array}$ \\
\hline 2 & Dr. Bagwan Das & $\begin{array}{l}\text { Contribution in data analysis, } \\
\text { Introduction }\end{array}$ \\
\hline 3 & Dr. Agha Taj & $\begin{array}{l}\text { Contrubition, Discusstion } \\
\text { Reference, Collection of sample }\end{array}$ \\
\hline 4 & Dr. Santosh Kumar & Contribution, Results \\
\hline 5 & Besham Kumar & Biostatistical \\
\hline
\end{tabular}

Author $=\mathbf{s}$ Signature 